\title{
Nem tumoros nyelőcső-perforáció mütéti kezelésével szerzett tapasztalataink
}

\author{
Operative treatment of non-malignant esophageal perforations - \\ a summary of our experiences
}

\author{
BARANYAI ZSOLT ${ }^{@}$, BALÁZS ÁKOS, KUPCSULIK PÉTER, HARSÁNYI LÁSZLÓ \\ Semmelweis Egyetem, I. sz. Sebészeti Klinika (Igazgató: Dr. Harsányi László, egyetemi tanár)
}

\begin{abstract}
Bevezetés: A sebészi és az intenzív terápia jelentős fejlődése ellenére a nyelőcső-perforáció napjainkban is súlyos, életet veszélyeztető állapot. A sikeres kezelés függ a különböző klinikai tényezőktől, az egészségügyi felszereltségtől, de leginkább a rendelkezésre álló szaktudástól, tapasztalattól. Betegek és módszerek: Retrospektív módon elemeztük a Semmelweis Egyetem I. sz. Sebészeti Klinikáján 2005 és 2017 között nem tumoros eredetű nyelöcsö-perforáció miatt mütéttel kezelt betegek adatait. Eredmények: A fenti időszak alatt 77 beteget kezeltünk, mindegyikük külső intézetből került átvételre. 15 beteg (19\%) sokkos állapotban érkezett. A perforáció 29 (38\%) esetben spontán, 32 (41\%) alkalommal endoszkópia során, $12(16 \%)$ betegnél idegentest-elakadás miatt, $4(5 \%)$ esetben pedig nyelöcsővarix-vérzés ballon-kompressziós terápiája után alakult ki. A betegek a tünetek kialakulása után átlagosan 2,7 nappal kerültek klinikánkra. 11 (14\%) betegnél drainage-t, $6(8 \%)$ alkalommal suturát, $8(10 \%)$ funduplicatiót, illetve 19 (25\%) betegnél nyelőcső-kirekesztést alkalmaztunk. Reoperációkkal együtt 33 (43\%) betegnél pedig teljes oesophagus exstirpatióra kényszerültünk. 27 (36\%) beteget vesztettünk el. Megbeszélés, következtetések: A nyelőcsősérülések sebészi ellátását alapvető két tényező befolyásolja: a mütét előtti észlelési idő hossza és a szeptikus tünetek fennállása. Alapvetően a késedelem miatt kényszerülünk radikális - csonkító - mütétekre. Az időveszteség oka a nem egységes diagnosztikai stratégiában, a valós diagnózis felismerésének késedelmében rejlik.
\end{abstract}

Kulcsszavak: nyelőcső-perforáció, sebészi kezelés, nyelőcső-exstirpáció

Introduction: Despite significant development in surgical and intensive therapy, esophageal perforation is still a severe, life-threatening condition. Successful therapy depends on several clinical factors, available medical equipments, but most of all on the available expertise and experience. Patients and methods: We retrospectively evaluated patients' data operated at the 1st Department of Surgery at Semmelweis University between 2005 and 2017 due to esophageal perforation of non-malignant origin. Results: During the period above 77 patients were treated. All of them were referred to us from an external institute. 15 patients $(19 \%)$ arrived in shock. The patients developed perforation in 29 cases spontaneously (38\%), in 32 cases (41\%) during endoscopy, in 12 cases (16\%) due to food bolus impaction, and in 4 cases (5\%) following balloon tamponade of esophageal variceal bleeding. Patients were sent to our clinic 2.7 days after the presentation of the symptoms. In 2 patients $(2 \%)$ drainage, in 6 patients $(8 \%)$ suture, in 8 patients $(12 \%)$ funduplication, in 19 patients (28\%) esophageal exclusion, and in 33 patients (50\%) total esophageal extirpation had to be done. 27 patients (35\%) died. Discussion, conclusion: Surgical treatment of esophageal injuries is basically influenced by two factors: observation time before surgery and the presence of sepsis symptoms. We have to perform radical surgery basically due to delay. Waste of time is caused by the non-uniform diagnostic strategy and the delay in the true diagnosis.

Keywords: esophageal injuries, surgical treatment, esophageal exstirpation

Beérkezett: 2018. november 12.; elfogadva: 2018. december 7.

\section{Bevezetés}

A nyelöcső-perforáció súlyos, életet veszélyeztető állapot. A gyorsan kialakuló mediastinitis, szeptikus állapot magas morbiditással és mortalitással jár. Az irodalomban közölt halálozási arányok 10-60\% között változnak, a prognózis függ az etiológiától és a kezelés megkezdéséig eltelt időtől. ${ }^{1-4}$ A kórkép viszonylagos ritkasága és a megjelenés változékonysága miatt diagnosztikai és terápiás kihívás. A nyelőcső perforációjának főbb etiológiai okai iatrogén,

\footnotetext{
@Levelezési cím/Corr. address: Dr. Baranyai Zsolt, Semmelweis Egyetem, I. sz. Sebészeti Klinika, 1082 Budapest, Üllői út 78. Tel.: +36 20/825-8922; E-mail: baranyai.zsolt@med.semmelweis-univ.hu
} 
traumás, spontán és idegen test eredetűek. ${ }^{5-7}$ A kezelés eredményességét befolyásolja a beteg életkora, általános állapota, kísérö betegségei, az egyidejüleg fennálló nyelöcsőbetegsége, a perforáció mérete, helye, kiváltó oka, valamint a ruptura és a kezelés megkezdése között eltelt idő, ${ }^{8,9}$ de a leglényegesebb szempont a kezelési stratégia, mely főleg a rendelkezésre álló szaktudáson, tapasztalaton alapszik.

\section{Anyag és módszerek}

Retrospektív módon elemeztük a Semmelweis Egyetem I. sz. Sebészeti Klinikáján 2005 és 2017 között nem tumoros eredetü, nyelőcső-perforációval kezelt betegek kórtörténetét. A fenti időszak alatt 77 beteget operáltunk, mindegyikük más intézetből került átvételre. Felmérésünk nem terjedt ki a konzervatív módon kezelt esetekre. Vizsgáltuk a prediszponáló tényezőket, a tüneteket, a kiváltó okot, a diagnosztikai vizsgálatokat, a perforáció lokalizációját, méretét, a beavatkozásig eltelt időt, a kezelés módját, a beavatkozás utáni időszakot és a kórkép kimenetelét. A betegek egy része a posztoperatív szakban rehabilitációra más intézetbe került áthelyezésre.

\section{Eredmények}

Az esetek 27\%-ának volt a perforációra prediszponáló tényezője (1. táblázat). Viszonylag kis számban találtunk a háttérben korábban lezajlott korrozív nyelöcsősérülést, mütétet (diverticulumok miatt) vagy dilatációt. Perforáció előtt a betegek 15\%-ának volt ismeretlen eredetü dysphagiája, motilitási zavara, közülük 7 eset többszöri tágító kezelést is igényelt. A vezető tünet a subcutan emphysema és a fájdalom volt. Négy beteg teljesen tünetmentes volt, azonban 16 páciens súlyos szeptikus sokk állapotában került felvételre. Az összes nyelőcső-perforáció közel fele iatrogén volt, ezek többsége endoszkópos vizsgálat vagy beavatkozás során keletkezett. 17 esetben a gasztroenterológus nem észlelte a sérülés kialakulását. A klinikánkra irányított betegek 44\%-ának nem történt adekvát vizsgálata a küldő intézetben. A perforációtól az észlelésig eltelt átlagidő 2,7 nap (0-8,1 nap) volt.

1. táblázat. Prediszponáló faktorok, tünetek, vizsgálatok

\begin{tabular}{lc}
\hline Esetszám & 77 \\
Átlagkor (év) & $66(31-98)$ \\
Nem & ffi: 48, nő: 29 \\
Alkoholaddikció & 17 \\
Nicotinaddikció & 9 \\
\hline Prediszponáló faktorok & \\
Korrozív nyelöcsősérülés & 4 \\
Nyelőcsőmütét & 3 \\
Pneumatikus dilatáció (achalasia, korrózió) & 3 \\
Dysphagia, motilitási zavar & 10 \\
\hline
\end{tabular}

1. táblázat. (folyt.)

\begin{tabular}{lc}
\hline Vezetö tünetek & \\
Tünetmentes & 4 \\
Fájdalom & 31 \\
Láz & 1 \\
Subcutan emphysema & 58 \\
Ptx & 12 \\
Súlyos septicus állapot & 15 \\
\hline Kiváltó ok & \\
Iatrogén & $36(47 \%)$ \\
Varixvérzés ballon-kompressziós terápiája & $4(5 \%)$ \\
Endoscopos vizsgálat vagy beavatkozás & $32(42 \%)$ \\
Spontán (Boerhaave-szindróma) & $29(38 \%)$ \\
Idegentest-nyelés & $12(15 \%)$ \\
\hline Vizsgálat & \\
Küldö intézet & $43(56 \%)$ \\
$\quad$ Vízoldékony kontrasztanyag nyeletése & 15 \\
CT & 23 \\
Endoscopia & 5 \\
Saját & $34(44 \%)$ \\
Vízoldékony kontrasztanyag nyeletése & 13 \\
CT & 13 \\
Endoscopia & 8 \\
\hline
\end{tabular}

Betegeink döntő részénél a nyelöcső mellkasi szakaszán alakult ki sérülés. Ezen belül 62\%-ban az alsó harmad rupturája fordult elő leggyakrabban. Az összes perforációnk transmurális volt. $1 \mathrm{~cm}$ alatti léziót relatíve keveset operáltunk, mütéteink nagy része igen kiterjedt méretű perforáció miatt történt (2. táblázat).

A mediastinum és nyelőcsőlumen belső drenázsa 2 esetben bizonyult elégségesnek, a perforatiós nyílás gyomorfundussal való fedése (fundoplicatio) külső-belső drenázzsal 8 esetben, a nyelőcső kirekesztése (loop oesopha-

2. táblázat. A perforációk lokalizációja és mérete

\begin{tabular}{lc}
\hline Lokalizáció & Esetszám \\
\hline Nyaki szakasz $(18 \mathrm{~cm}-\mathrm{ig})$ & $4(5 \%)$ \\
Mellkasi szakasz & $69(90 \%)$ \\
Felső harmad $(18-24 \mathrm{~cm})$ & 5 \\
Középső harmad $(24-32 \mathrm{~cm})$ & 16 \\
Alsó harmad $(32-40 \mathrm{~cm})$ & 48 \\
\hline Hasi szakasz & $3(4 \%)$ \\
Teljes elhalás & 1 \\
\hline Méret & Esetszám \\
\hline$<1 \mathrm{~cm}$ & $24(31 \%)$ \\
$1-3 \mathrm{~cm}$ & $28(36 \%)$ \\
$>3 \mathrm{~cm}$ & $25(33 \%)$ \\
\hline
\end{tabular}


3. táblázat. Mütéti típusok: Reoperáció során subtotalis exstirpatio történt

\begin{tabular}{lccc}
\hline Mütéti megoldás & Esetszám & Reoperatio & Exitált \\
\hline Sebészi drainage (mediastinum és nyelőcsőlumen) & $11(14 \%)$ & $9 *$ & 0 \\
Sutura & $6(8 \%)$ & $0^{*}$ & $2(3 \%)$ \\
Funduplicatio + sebészi drainage & $8(10 \%)$ & $0^{*}$ & $2(3 \%)$ \\
Exclusio & $19(25 \%)$ & $0^{*}$ & $3(4 \%)$ \\
Primer és reoperatio során* subtotalis exstirpatio & $24+9 *(43 \%)$ & - & $14+6^{*}(26 \%)$ \\
\hline
\end{tabular}

gostomia, occlusio gépi kapocssorral, drainage, supportiv táplálási lehetőség kialakítása - gastrostomia vagy jejunostomia) 19 esetben, a nyelőcső subtotalis exstirpatiója a reoperált esetekkel együtt 33 esetben vált szükségessé. Az exstirpatiót Oringer módszerével transhiatalisan végeztük. A betegek 36\%-át vesztettük el (3. táblázat). A subtotalisan extirpált betegek közül 8 beteg tápcsatornáját rekonstruáltunk.

\section{Megbeszélés}

A nyelőcső-perforáció klinikai megjelenése elsősorban a perforáció helyétől függ. Betegeink vezető tünetei is megfeleltek az irodalomban általában leírt megoszlásoknak. Az irodalmi adatok 15\%-os gyakoriságával szemben magas, 38\%-os volt a spontán perforációk aránya. ${ }^{10}$ A kiváltó okok között azonban vezetett a iatrogén endoszkópos lézió. Saját anyagunkban 17 esetben nem ismerték fel a beavatkozás során a léziót. Az endoszkópia során bekövetkező nyelöcsősérülések száma a jövőben valószínüleg növekedni fog a terápiás endoszkópia indikációjának folyamatos bővülésével. A betegek nagyobb biztonságban lennének, ha az endoszkópos intervenció levegőbefúvás helyett szén-dioxiddal történne, azonban erre a nálunk fejlettebb országokban sincs általában forrás. Az általunk operált betegek 27\%-ának volt azonban olyan prediszponáló tényezője, mely az endoszkópos vizsgálatnál nagyobb figyelmet igényelt volna, illetve ismeretében gyorsabban történhet a ruptura diagnózisának a felállítása.

A nyelőcső-perforáció sikeres kezelésének egyik kulcsa a perforációtól az első észlelésig eltelt idő. Egy nagy amerikai tanulmányban Abbas ezt az időt átlagosan 12 órának mérte. ${ }^{11}$ Saját anyagunkban ez átlagban 2,7 nap volt. Az eseteknek csak a $27 \%$-a volt 24 órán belüli. A diagnosztikus késés mellett további probléma, hogy a beutalt betegek 44\%-ának nem történt adekvát vizsgálata a küldő intézetben. Ezek elvégzése óhatatlanul is további időveszteséggel járt.

$\mathrm{Az}$ oesophagusperforáció diagnosztikájában a körültekintő anamnézisfelvétel, a tünetek és fizikális jelek megfigyelése alapvető. Nyaki perforatiónál oldalirányú röntgenfelvételen sokszor a tapintható crepitatio előtt a prevertebralis régióban mutatható ki levegő. A mellkasi szakaszú léziók esetén az első órákban végzett röntgen sokszor negatív. A mediastinalis emphysema kialakulásához a sérülés után legalább egy órára van szükség. A röntgen- felvétel azonban még előrehaladott állapotban sem mindig pozitív, ezért negatív lelet alapján nem lehet elvetni a klinikai gyanút. A nyelőcsősérülések kulcsfontosságú vizsgáló módszere a vízoldékony kontrasztanyag használata. A helyes vizsgálathoz a beteget nem csak álló testhelyzetben kell vizsgálni. Az oldalsó és Trendelenburg-helyzetben a kontrasztanyag lassabban ürülve nagyobb biztonságú eredményt ad. Ha a vizsgálat negatív eredményt ad, de a perforáció klinikai gyanúja erős, akkor a nyálkahártyához jobban tapadó bárium, különösen a nyaki szakaszon, kisebb rupturát is kimutathat. CT-vizsgálat a perforáció hátterében lévő okokra vonatkozóan is szolgáltathat további fontos információt. Endoszkópia diagnózisra történő használata vitatott. Amennyiben a nyelőcső-perforáció endoszkóppal ellátható (hemoklipek, „over the scope” klipek, stentek), az endoszkópia előnye felmerül. Kis, spontán letapadási hajlamot mutató lézió esetén azonban fokozhatja a sérülés mértékét.

Általánosságban pontokba szedve a következő alapelveket lehet felállítani az oesophagusperforációk kezelésével kapcsolatban:

- gyors diagnózis,

- megfelelő hemodinamikai monitorozás és támogatás,

- antibiotikus kezelés,

- ha megvalósítható, a lumen integritásának helyreállítása,

- extraluminalis contaminatio megszüntetése.

A nyelőcső-perforáció műtét nélküli kezelése alatt a per os táplálékfelvétel minimálisan hét napos teljes tilalmát, széles spektrumú antibiotikum-kombináció adását és parenteralis hyperalimentatio bevezetését érjük. A konzervatív kezelés lehetőségét Shaffer három kritérium alapján tartja eredményesen kivitelezhetőnek: 1) klinikailag stabil állapot, 2) a perforatió időpontja régebbi és a beteg kielégítően tolerálta az azóta eltelt időt, 3) a perforáció nem okozott jelentősebb mediastinitist és pleuralis inflammatiót. ${ }^{12}$ Cameron megállapítása szerint csak azon kis laesiók kezelhetők konzervatívan, ahol nincs kimutatható mediastinalis vagy pleuralis contamináció. ${ }^{13}$ A nem operatív kezelési formák közé tartoznak az egyre gyakrabban és egyre szélesebb körben alkalmazott endoszkóppal bevezetett stentek (döntően bevont, öntáguló protesissek) és hemoklipek. Ezek alkalmazásakor is gondoskodni kell a sérülés környezetében kialakult váladékgyülem (pl. CT-vezérelt drainage) elvezetéséről. Az utóbbi időkben endoluminaris VAC-terápia is egyre nagyobb teret nyer. 
A mütéti kezelés módjában nincs egységes álláspont. A nyelőcső különböző szakaszainak sérülése más-más ellátási taktikát igényel. Az oesophagus nyaki szakaszának izolálált, kis sérülése általában nem igényel mútéti ellátást, legtöbbször elegendő a carentia és antibiotikum adása. Tályogképződés drainage-t igényelhet. Nagyobb, áthatoló sérülés esetén sutura válhat szükségessé.

Irodalmi adatok alapján a 24 órán belül diagnosztizált, a nyelöcső mellkasi/hasi szakaszán létrejött, komplett nyelöcsőruptura eseteiben, ahol nincs egyéb nyelöcső-társbetegség, az oesophagus primer varrata, mediastinalis és mellkasi drenázzsal kiegészítve, mintegy 90\%-os sikerrel alkalmazható. Abbot a perforatiók mütéti kezelésére T-tube drainage beültetését javasolta, mely 3 hetes szívó kezelést igényelt. ${ }^{12,14}$ Ilyenkor a szövetek még nem ödémásak, jól varrhatóak, és a mellkasban aktív bakteriális fertőzés sem alakult ki. ${ }^{15-17}$ A nyelőcső-perforáció nyílásának zárását követően a varratvonal fedése nyeles pleura- vagy izomlebennyel (rekesz vagy intercostális) évtizedek óta ismert eljárás.

Mások azonban a gyulladás miatt eleve kizárják a biztonságos varrat készítésének lehetőségét, és akut megoldásként a nyelőcső kirekesztését vagy az azonnali reszekciós mütétet ajánlják. ${ }^{18}$ Abban viszont egyöntetü az álláspont, hogy a későn, 24 órán túl felfedezett nyelőcső-perforációk megoldása a nyelöcső exstirpatiója. ${ }^{10}$ Úgy gondoljuk, hogy elörehaladott esetekben ez a mütéti megoldás egyszerre szünteti meg az intrathoracalis szepszis forrását, az oesophaguson található perforációt és távolítja el a beteg nyelöcsövet. Transhiatalis behatolásból a mediastinum drenázsa megfelelöen kivitelezhető. Körülírt mellkasi levegö- vagy folyadékgyülem esetén pedig mellkasi drenázs végezhető. Ha csak lehet, a thoracotomiát kerüljük. A mellüreg és a hasüreg megnyitása, pláne az esetleges rekeszérintettséggel együtt, a légzés dinamikáját jelentősen rontja. Fundoplicatióval nem csak a cardia közeli perforatiós nyílás fedése biztosítható. Exclusio esetén megakadályozza a gyomor felöli refluxot. Abban az esetben, ha a primer mütét nem hozza meg az eredményt, reoperációra van szükség, és ez gyakran a nyelöcső exstripatióját jelenti. Esetünkben ez 9 esetet jelentett.

A reszekciót primer vagy halasztott pótlás követheti. A pótlás történhet csövesített gyomorral és vastagbéllel. Lényeges, hogy a pótlásra használt szerv ép, a feszülésmentes anasztomózis képzéséhez megfelelő hosszúságú legyen, illetve kifogástalan artériás és vénás vérellátással rendelkezzen.

A nemzetközi statisztikák a nyelöcsőperforáltak túlélését 10 és $60 \%$ közé teszi. ${ }^{6,11,19,20} \mathrm{Mi}$ a betegek $35 \%$-át, 27 beteget vesztettünk el. Irodalmi adatok a nyelöcsö-perforációk 10-30\% közötti mortalitásának 40-60\%-ra való emelkedését észlelték, a mütéti kezelésnek a perforáció időpontjától számított 24 órán túli végzése esetén. ${ }^{5}$ Felmérésünk nem tartalmazta sem a tumoros eseteket, sem a konzervatív terápiában részesülteket.

Érdekes kérdés a betegek kezelésére fordított erőfeszítés mértéke. A betegek átlagosan 13 napot töltöttek inten- zív osztályon, ami után szintén átlagosan 29 napig kezeltük őket a sebészeten. Mivel minden beteget más intézetböl vettük át, a tetemes kezelési, ápolási költség komoly finanszírozási kérdéseket is felvet.

\section{Összefoglalás}

Az oesophagusperforáció igen magas morbiditási és mortalitási aránnyal járó kórkép. Sikeres kezeléséhez a két legfontosabb tényezö a kialakulástól az észlelésig eltelt időtartam, valamint a szeptikus tünetek fennállása. Éppen ezért oesophagusperforáció gyanújakor a diagnózis minél előbbi felállítására kell törekedni. 24 óra után és szeptikus tünetek fennállása esetén sebészi beavatkozás szükséges. Elörehaladott esetekben - melyeket a saját beteganyagunk is tartalmaz - a mütétek széles variációs lehetősége beszükül. Ezekben az esetekben jó eredményeket tapasztaltunk a transhiatalis oesophagusexstirpatióval. A kezelés elsősorban centrumokban kell történjen, ahol megfelelő radiológiai, aneszteziológiai-intenzív terápiás szakértelem áll rendelkezésre. A terápia sikerességét a korai diagnózis mellett a gondosan megválasztott mütéti technika biztosítja. Ezért fontos a sebész szaktudása, valamint a kis esetszám miatt a tapasztalata.

\section{Irodalomjegyzék}

${ }^{1}$ Skinner DB, Little AG, DeMeester TR: Management of esophageal perforation. Am J Surg 1980; 139: 760-764.

2 Bufkin BL, Miller JI, Mansour KA: Esophageal perforation: emphasis on management. Ann Thorac Surg 1996; 61: 1447-1451.

${ }^{3}$ Jones WG, Ginsberg RJ: Esophageal perforation: a continuing challenge. Ann Thorac Surg 1992; 53: 534-543.

${ }^{4}$ Vogel SB, Rout WR, Martin TD, Abbitt PL: Esophageal perforation in adults: aggressive, conservative treatment lowers morbidity and mortality. Ann Surg 2005; 241: 1016-1021.

${ }^{5}$ Altorjay A, Kiss J, Vörös A, Szirányi E: The role of esophagectomy in the management of esophageal perforations. Ann Thorac Surg 1998; 65: 1433-1436.

${ }^{6}$ Gupta NM, Kaman L: Personal management of 57 consecutive patients with esophageal perforation. Am J Surg 2004; 187: 58-63.

${ }^{7}$ Iannettoni MD, Vlessis AA, Whyte RI, Orringer MB: Functional outcome after surgical treatment of esophageal perforation. Ann Thorac Surg 1997; 64: 1606-1609.

${ }^{8}$ Hasan S, Jilaihawi AN, Prakash D: Conservative management of iatrogenic oesophageal perforations - a viable option. Eur J Cardiothorac Surg 2005; 28: 7-10.

${ }^{9}$ Chirica M, Champault A, Dray X, Sulpice L, Munoz-Bongrand $N$, Sarfati E, Cattan P: Esophageal perforations. J Visc Surg 2010; 147: 117-128.

${ }^{10}$ Biancari F, D'Andrea V, Paone R, Di Marco C, Savino G, Koivukangas V, Saarnio J, Lucenteforte E: Current treat- 
ment and outcome of esophageal perforations in adults: systematic review and meta-analysis of 75 studies. World J Surg 2013; 37: 1051-1059.

11 Abbas G, Schuchert MJ, Pettiford BL, Pennathur A, Landreneau J, Landreneau J, Luketich JD, Landreneau RJ: Contemporaneous management of esophageal perforation. Surgery 2009; 146: 749-755.

12 Shaffer HA, Valenzuela G, Mittal RK: Esophageal perforation. A reassessment of the criteria for choosing medical or surgical therapy. Arch Intern Med 1992; 152: 757-761.

${ }^{13}$ Cameron JL, Kieffer RF, Hendrix TR, Mehigan DG, Baker RR: Selective nonoperative management of contained intrathoracic esophageal disruptions. Ann Thorac Surg 1979; 27: 404-408.

${ }^{14}$ Abbott OA, Mansour KA, Logan WD Jr, Hatcher CR Jr, Symbas $P N$ : Atraumatic so-called "spontaneous" rupture of the esophagus. A review of 47 personal cases with comments on a new method of surgical therapy. J Thorac Cardiovasc Surg 1970; 59: 67-83.
${ }^{15}$ Lazar, G., Paszt A, Simonka Z, Bársony A, Abrahám S, Horváth $G$ : Surgical treatment of Boerhaave's syndrome. Orv Hetil 2000; 141: 2255-2258.

${ }^{16}$ Ayed AK, Al-Din HJ, Asfar SK: Reinforced primary repair of early distal oesophageal perforation. Eur J Surg 2000; 166: 938-941.

${ }^{17}$ Cho JS, Kim YD, Kim JW, I HS, Kim MS: Thoracoscopic primary esophageal repair in patients with Boerhaave's syndrome. Ann Thorac Surg 2011; 91: 1552-1555.

18 Orringer MB, Stirling MC: Esophagectomy for esophageal disruption. Ann Thorac Surg 1990; 49: 35-42.

19 Paspatis GA, Dumonceau JM, Barthet M, Meisner S: Diagnosis and management of iatrogenic endoscopic perforations: European Society of Gastrointestinal Endoscopy (ESGE) Position Statement. Endoscopy 2014; 46: 693-711.

${ }^{20}$ Lawrence DR, Moxon RE, Fountain SW, Ohri SK, Townsend ER: Iatrogenic oesophageal perforations: a clinical review. Ann R Coll Surg Engl 1998; 80: 115-118.

A cikk a Creative Commons Attribution 4.0 International License (https://creativecommons.org/licenses/by/4.0/) feltételei szerint publikált Open Access közlemény, melynek szellemében a cikk bármilyen médiumban szabadon felhasználható, megosztható és újraközöl= hetö, feltéve, hogy az eredeti szerző és a közlés helye, illetve a CC License linkje és az esetlegesen végrehajtott módosítások feltüntetésre kerülnek. (SID_1) 